\title{
Censuses of breeding birds in a South Norwegian arctic-alpine habitat three decades apart show population declines in the most common species
}

\author{
Ingvar Byrkjedal ${ }^{1} \&$ John Atle Kålås ${ }^{2}$ \\ ${ }^{1}$ University Museum of Bergen, University of Bergen, Allégt. 41, P.O. Box 7800, NO-5020 Bergen, Norway. E-mail: \\ ingvar.byrkjedal@um.uib.no. ${ }^{2}$ Norwegian Institute for Nature Research, P.O. Box 5685 Sluppen, NO-7485 Trondheim, Norway. \\ E-mail: john.a.kalas@nina.no
}

\begin{abstract}
Breeding bird censuses along line transects on the Hardangervidda plateau, southern Norway, were performed on open mountain heath at about1250 m elevation in 1980 and repeated in 2010 and 2011. Four passerine species and three species of waders constitute the commonest breeders. Significant decrease in numbers was found in the three commonest species, Meadow Pipit Anthus pratensis (down $40 \%$ ), Northern Wheatear Oenanthe oenanthe (down 65-67 \%) and, in particular, Lapland Bunting Calcarius lapponicus (down 82-87 \%). The decline in Lapland Bunting is discussed in relation to changes in the vegetation on the breeding grounds probably caused by reduced grazing and climatic changes, and in relation to possible negative factors in parts of the wintering area.
\end{abstract}

Key words: Montane birds; population changes; passerines; waders

\section{INTRODUCTION}

With their virtual lack of permanent (year round) human inhabitation, Scandinavian mountainous areas above the tree-line are relatively little affected by human activities (e.g. Østbye et al. 1975, Ottvall et al. 2008, Austrheim et al. 2010, Thompson et al. 2012). Traditionally the areas are used for sheep-grazing, and like most of Scandinavia have received acidic depositions and other airborne pollutants over the last decades. However, by and large the areas show an environmental stability over long periods of time. Arctic-alpine mountain heaths characteristically have a terrestrial avifauna dominated by a few passerine species, and among non-passerines primarily represented by several species of waders. In spite of the apparent stability of these areas, bird populations can fluctuate substantially (Moksnes 1973, Lien 1974, Järvinen \& Rajasärkkä 1992). Many species of open farmland habitats have shown population declines over the last decades, often as a result of agricultural practices and other human activities (e.g., BirdLife International 2004, Pan-European Common Bird Monitoring Scheme 2011). In Europe moderate to strong declines are reported for species like Meadow Pipit Anthus pratensis, Wheatear Oenanthe oenanthe, and Redshank Tringa totanus, which also occur in the mountainous areas of Scandinavia, whereas many of the more typical mountainous species, such as Eurasian Golden Plover Pluvialis apricaria, Eurasian
Dotterel Charadrius morinellus, and Lapland Bunting Calcarius lapponicus, are considered to have had stable population trends.

In the 1980s we performed breeding bird censuses in open alpine habitat in the upper part of the shrub zone about $1250 \mathrm{~m}$ a.s.l. on the Hardangervidda plateau, southern Norway, by line transect counts according to the method introduced by Järvinen \& Väisänen (1973, 1975). From casual visits over the years we have had the impression that relatively large changes in the numbers of some species were taking place. We repeated censuses along the same line transects in 2010 and 2011 to look for indications of population changes of birds in these mountains in the 30-year time span since the first censuses.

\section{STUDY AREA AND METHODS}

The censuses were made in Steinbuheii, Hardangervidda between 1180 and $1280 \mathrm{~m}$ a.s.l., well above the treeline. The vegetation consists of a mosaic of alpine meadow and bog vegetation (Graminaeae, Ericaceae), lichen heath, and patches of prostrate Betula nana (Kålås \& Byrkjedal 1984).

The censuses were done along ten stretches, each one $\mathrm{km}$ long (Figure 1). The census line pattern was chosen partly in order to keep the censuses within the same general habitat, partly for practical logistic 


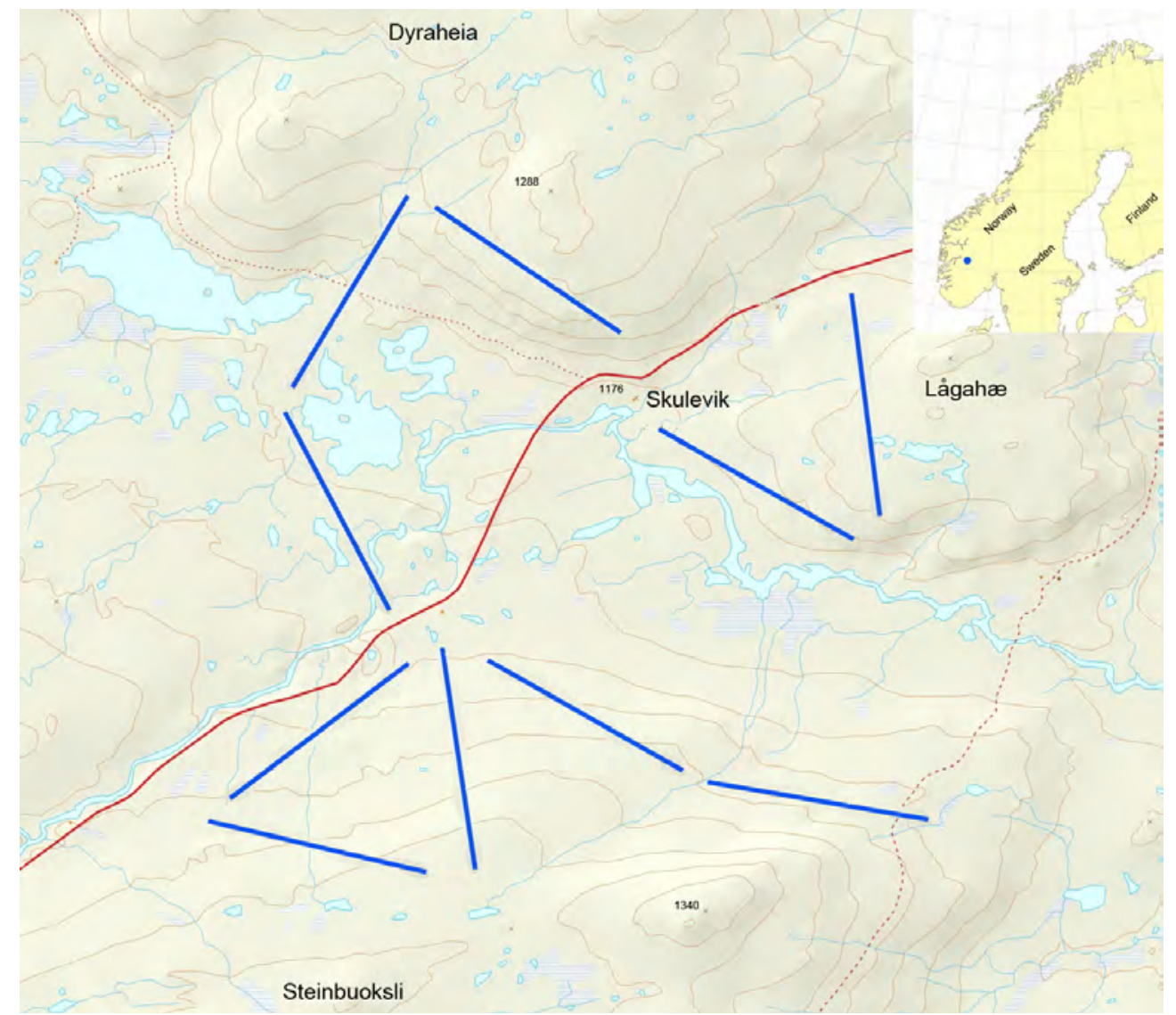

Figure 1. Transects covered in 1980 and repeated in 2010 and 2011 shown in blue. The transect was composed of 10 lines, each line $1 \mathrm{~km}$ long. Location of study area indicated by blue dot on inserted map.

reasons. While walking the transects on compass bearings, we recorded birds inside the "main belt" ( $\leq$ $25 \mathrm{~m}$ to each side of the line) and in the "supplementary belt” ( $>25 \mathrm{~m}$ to each side of the line). Pairs, singing males, and non-singing males, were counted as "pairs". Only birds seen in front of the observer were included, to avoid double counts. A $25 \mathrm{~m}$ long rope was trailed behind the observer to provide a reference scale for main belt and the distance covered. The walking speed was kept as close as possible to $1 \mathrm{~km}$ per hour. The censuses were carried out in the time period from 0500 to 1000 (CET), in 1980 divided on the dates 12-13 June in 1980, 11 June in 2010, and 13 and 15 June in 2011. At this time of the year most of the birds in the area are in the pre-laying or incubation phase. For passerines, this is an optimal time for census while males readily expose themselves and their song activity is high, whereas waders may be more difficult to observe once they start incubating (Kålås \& Byrkjedal 1984). A fairly long morning period was chosen for census. This works well in open mountains, as visual observations form an important part of the registrations; besides, morning song chorus is far less marked in open mountains than in dense forest, and the censuses fell within the time of day when there is most bird-song.

In mountains the distribution of ground-nesting birds can be affected by variations from one year to another in the persistence of remaining winter snow (personal obs.). On each census the extent of snow-patches was drawn on maps of the main belt, and the per cent snow cover calculated from this was considered an indication of the general snow cover. In 1980, 6.4\% of the ground was covered by winter snow, while in 2010 and 2011 the figures were $41.0 \%$ and $11.6 \%$, respectively.

The data were compared across the years by chi-square tests separately for each of the species, partitioning performed according to Siegel \& Castellan (1988) for species that showed statistical significant differences across the years, in order to find between which years the differences were located. The data were tested without any conversion to pairs per $\mathrm{km}^{2}$, since exactly the same transects were followed each year. This also avoids the use of conversion constants which ideally should be calculated from larger sample sizes than obtained by us (cf. Järvinen \& Väisänen 1983).

\section{RESULTS}

In 1980, 397 pairs of 15 species were recorded, in 2010, 215 pairs of 19 species, and in 2011, 175 pairs of 16 species. The eight most common species are shown in 


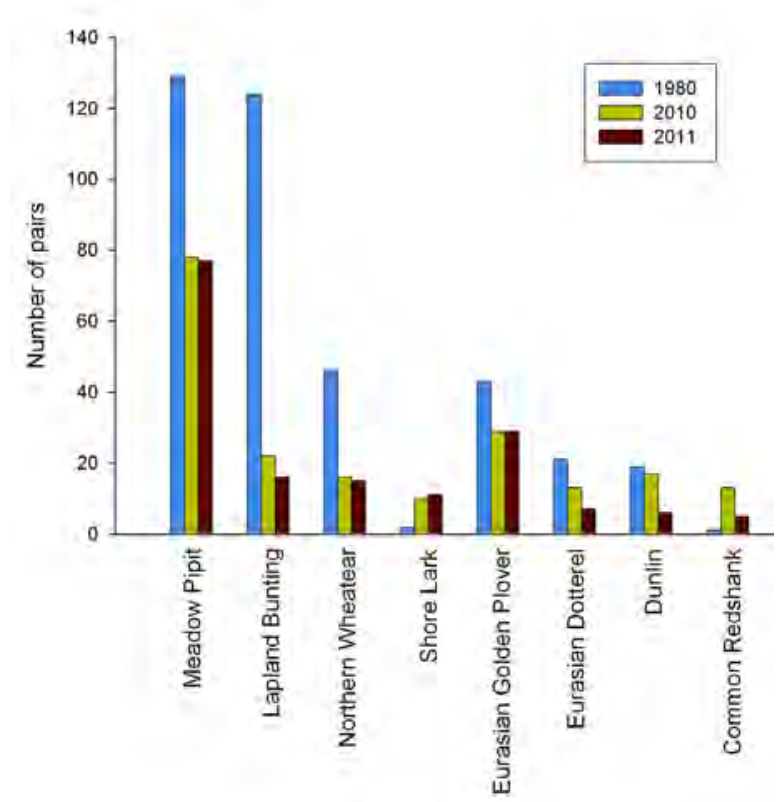

Figure 2. Number of pairs in a $10 \mathrm{~km}$ line transect at Steinbuheii, Hardangervidda, surveyed in 1980 (blue columns), and repeatedly in 2010 (green columns) and 2011 (brown columns). Only the 8 most numerous species shown.

Figure 2. Other species were represented only by 1 2 pairs (Common Teal Anas crecca, Common Kestrel Falco tinnunculus, Merlin F. columbarius, Rock Ptarmigan Lagopus muta, Purple Sandpiper Calidris maritima, Common Sandpiper Actitis hypoleucos, Common Snipe Gallinago gallinago, Bluethroat Luscinia svecica, Fieldfare Turdus pilaris, Common Raven Corvus corax, and Common Redpoll Carduelis flammea).

Dominant species all three years were Meadow Pipit in 1980 closely followed by Lapland Bunting, and with Northern Wheatear in third place. All three species showed significantly lower numbers in 2010 and 2011 than in 1980 (Table 1), notably the Lapland Bunting for which the figures were $82-87 \%$ lower. The decrease in Northern Wheatear was 65-67\% and Meadow Pipit $40 \%$.

Eurasian Golden Plovers were 33 \% lower in numbers in 2010 and 2011 compared to 1980, and in two species, Common Redshank and Shore Lark Eremophila alpestris, number of pairs observed was higher in 2010 and 2011 than in 1980, but differences were not statistically significant for any of these species.

\section{DISCUSSION}

The much lower numbers of the three commonest species strongly indicate a marked population decline since 1980. Although numbers of any of the species fluctuate inter-annually in Scandinavian mountains (e.g. Moksnes 1973, Lien et al. 1974, Svensson 2006), the changes in numbers of Meadow Pipits, Wheatears and, in particular, Lapland Buntings, appear to be too large to be within the fluctuations normally seen in these species. Numbers in 2010 and 2011 were practically identical in spite of the vast snow cover in 2010 compared to 2011. The snow cover in 2011 was similar to that in 1980 , yet bird numbers were much lower in 2011. Thus, the variation in snow cover does not seem to explain the differences recorded in bird numbers.

While Meadow Pipit and Wheatear have shown declining trends in lowland populations elsewhere in Europe (Pan-European Common Bird Monitoring Scheme 2011), Lapland Buntings are reported as stable over the last three decades (BirdLife International 2004, Ottwall et al. 2008, Ottoson et al. 2012). The reason for the drastic decline in Lapland Buntings indicated by our material remains speculative, but one possibility

Table 1. Statistical tests on number of pairs across the three years (frequencies shown in Fig. 2 ); $\mathrm{df}=2$ for test of all years and $\mathrm{df}=1$ for partitioned $\chi 2$.

\begin{tabular}{|c|c|c|c|c|c|c|}
\hline Species & $\begin{array}{c}\chi^{2} \text { for all } \\
\text { years }\end{array}$ & $\mathrm{p}$ & $\begin{array}{l}\text { Partitioned } \chi^{2} \\
2010 \text { vs. } 2011\end{array}$ & $\mathrm{p}$ & $\begin{array}{c}\text { Partitioned } \chi^{2} \\
2010+2011 \\
\text { vs. } 1980\end{array}$ & $\mathrm{p}$ \\
\hline Meadow Pipit & 8.297 & $<0.02$ & 0.0000001 & n.s. & 10.115 & $<0.01$ \\
\hline Lapland Bunting & 61.630 & $<0.001$ & 0.001 & n.s. & 84.713 & $<0.001$ \\
\hline Wheatear & 10.809 & $<0.01$ & 0.000002 & n.s. & 14.078 & $<0.001$ \\
\hline Shore Lark & 4.225 & n.s. & & & & \\
\hline Eurasian Golden Plover & 1.176 & n.s. & & & & \\
\hline Dotterel & 3.718 & n.s. & & & & \\
\hline Dunlin & 4.247 & n.s. & & & & \\
\hline Redshank & 1.500 & n.s. & & & & \\
\hline
\end{tabular}



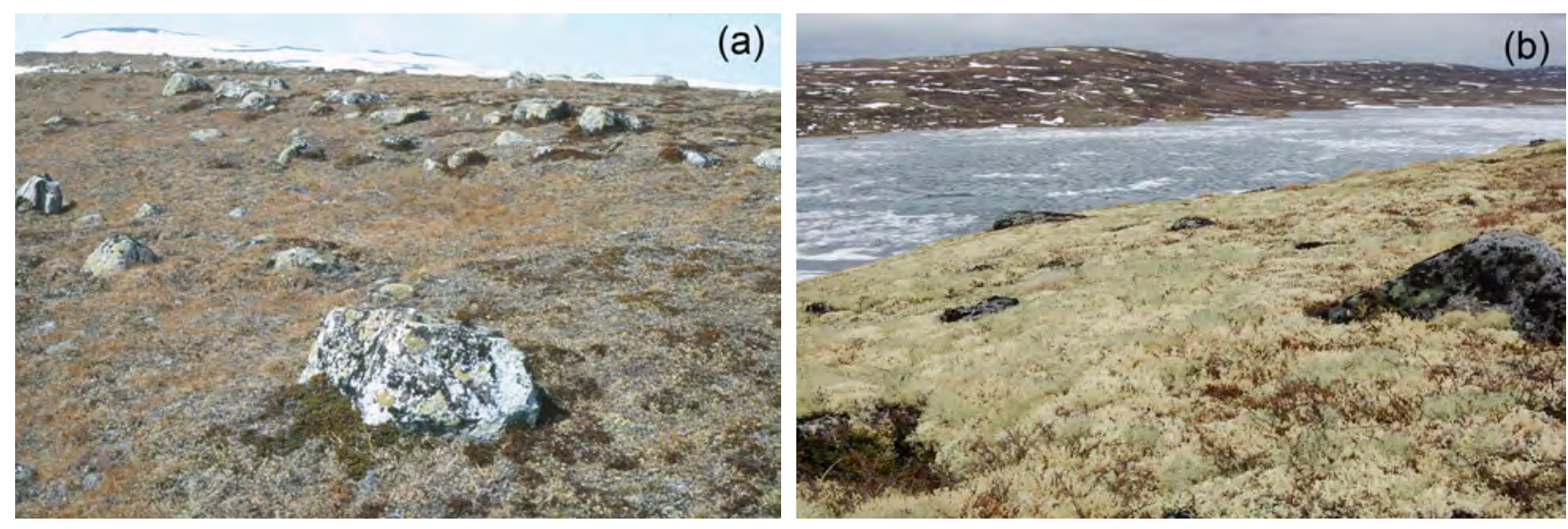

Figure 3. Examples of lichen cover on Juncus trifidus-Lichen heath in the study area in 1980 (a) and 2010 (b). The pictures are not from exactly the same spot.

may be linked to a pronounced increase in lichen mats causing habitat changes on the breeding grounds on Hardangervidda.

Since the 1980s, the Hardangervidda plateau has been subject to a substantial increase in the lichen mat (Cladonia, Cetraria, etc.) on exposed ground (Strand et al. 2005, Jordhøy \& Strand 2009), especially visible in Juncus trifidus-Lichen community commonly found on both smaller and larger hilltops (Figure 3). The increase of lichen cover may be a result of more persistent snow cover in recent years (possible climate change effect), a lower population of wild reindeer Rangifer tarandus (decreased grazing on lichens), and lower stocking of sheep in summer (reduced lichen abrasion from trampling by sheep). A thick and dense lichen mat may hamper growth of grasses, sedges and herbs that provide seed important as food for buntings in the period from arrival until egg-laying, during which a considerable part of the landscape may still be covered by winter snow. However, this should also affect Shore Larks, which are more or less granivorous in the same time period. Instead, Shore Larks seem rather to have increased in numbers in wider areas beyond the transects (personal obs.). The Lapland Bunting seems still to be common on Hardangervidda in the SalixBetula nana zone with taller bush growth, not covered by the present transect censuses. This habitat, which is generally favoured as breeding habitat by Lapland Buntings, is wetter with a ground far less overgrown by lichens, and a decline in bunting numbers may be slower to occur in favoured habitat than on the slightly marginal habitats of open heaths.

On Swedish breeding grounds Lapland Buntings have been found to decline in numbers since 1999 when breeding bird censuses started to obtain data for this species (Lindström et al. 2012), and these results indicate that negative population changes exist in Scandinavia beyond the limits of Hardangervidda. While some spend the winter around the North Sea, Scandinavian Lapland Buntings are largely thought to winter on steppes and other open habitat in Eastern Europe (Jacobsen 1963, Cramp \& Perrins 1994, Bakken et al. 2006). The latter received a massive fallout of radioactive isotopes in spring 1986, when the meltdown of the Chernobyl nuclear power plant took place (e.g. Medvedev 1986, Møller \& Mousseau 2006, Yablokov \& Nesterenko 2009). A possibility might exist that Lapland Buntings spending the winter in this area experience a lower fitness. Negative effects in the contaminated areas have been found in a number of organisms, including birds (Møller \& Mousseau 2006, Yablokov 2009). A more precise identification of the wintering grounds of Scandinavian Lapland Buntings is needed.

The line transect method usually performs well on passerine birds, while non-passerines may show a more variable detectability with stages in the breeding cycle (Kålås \& Byrkjedal 1984). Many wader species, while usually vocal and easily detected in the pre-laying period, tend to become utterly cryptic once the eggs are laid. With an earlier onset of breeding as expected from climatic changes, line transects on a fixed date could record fewer waders, thereby giving an impression of declining numbers while, in fact, more birds escape detection sitting on nests. We suspect that this could be the case with Eurasian Golden Plovers and Eurasian Dotterels in our material, although the lower numbers are not statistically different from the 1980 level.

In order to study population trends, censuses over a series of years would be strongly preferable to comparison of single censuses many years apart. However, our censuses do indicate declining numbers in some of the common species even in apparently pristine mountainous areas of southern Norway. In view of its apparently rather drastic decline a more detailed attention should be given to the Lapland Bunting to better understand its changes in numbers.

Acknowledgements. We are grateful to an anonymous reviewer for comments on the manuscript. 


\section{REFERENCES}

Austrheim, G., Bråthen, K.A., Ims, R.A. \& Ødegaard, F. 2010. Alpine environment. Pp. 107-117 in Kålås, J.A., Henriksen, S., Skjelseth, S. \& Viken, Å. (eds.). Environmental conditions and impacts for Red List species. Norwegian Biodiversity Information Centre, Norway.

Bakken, V., Runde, O. \& Tjørve, E. 2006. Norsk ringmerkingsatlas. Vol. 2. Stavanger Museum, Stavanger. (In Norwegian, English summaries.)

BirdLife International. 2004. Birds in the European Union: a status assessment. BirdLife International, Wageningen.

Cramp, S. \& Perrins, C.M. (eds.). 1994. The birds of the western Palearctic. Vol. 9. Oxford University Press, Oxford.

Jacobsen, J.R. 1963. Laplansværlingens (Calcarius lapponicus (L.)) træk og overvintring i Nordvesteuropa. Dansk Ornitologisk Forenings Tidsskrift 57: 181-220. (In Danish, English summary.)

Järvinen, A. \& Rajasärkkä 1992. Population fluctuations in two northern land bird communities: effects of habitat, migration strategy and nest-site. Ornis Fennica 69: 173183.

Järvinen, O. \& Väisänen, R.A. 1973. Species diversity of Finnish birds. I: Zoogeographical zonation based on land birds. Ornis Fennica 50: 93-125.

Järvinen, O. \& Väisänen, R.A. 1975. Estimating relative densities of breeding birds by the line transect method. Oikos 26: 316-322.

Järvinen, O. \& Väisänen, R.O. 1983. Correction coefficients for line transect censuses of breeding birds. Ornis Fennica 60: 97-104.

Jordhøy, P. \& Strand, O. 2009. Lufsjåtangen og Dagalitangen på Hardangervidda - kunnskap og utfordringar i høve til villreintrekk og menneskeleg arealbruk. NINA Rapport 412. (In Norwegian.)

Kålås, J.A. \& Byrkjedal, i. 1984. Line transects of waders in an alpine area: a methodological study. Ann. Zool. Fennici 21: 399-402.

Lien, L., Østbye, E., Hogstad, O., Haande, K.M., Haande, P.S., Hagen, A., Skar, H.-J., Skartveit, A. \& Svalastog, D. 1974. Bird surveys in the high mountain habitats of Finse and Stigstuv, Hardangervidda, South Norway, 19671972. Norwegian Journal of Zoology 22: 1-14.

Lindström, Å., Green, M. \& Ottvall, R. 2012. Övervakning av fåglarnas populationsutveckling. Årsrapport för 2011. Biologiska institutionen, Lunds universitet, Lund. (In Swedish, English summary.)

Medvedev, Z.A. 1986. Ecological aspects of the Chernobyl nuclear plant disaster. Trends in Ecology and Evolution 1: 23-25.
Moksnes, A. 1973. Quantitative surveys of the breeding bird populations in some subalpine and alpine habitats in the Nedal area in Central Norway (1967-71). Norwegian Journal of Zoology 21: 113-118.

Møller, A.P. \& Mousseau, T.A. 2006. Biological consequences of Chernobyl: 20 years after the disaster. Trends in Ecology and Evolution 21: 200-207.

Østbye, E., Berg, A., Blehr, O., Espeland, M., Gaare, E., Hagen, A. Hesjedal, O., Hågvar, S., Kjelvik, S., Lien, L., Mysterud, I., Sandhaug, A., Skar, H.-J., Skartveit, A, Skre, O., Skogland, T., Solhøy, T., Stenseth, N.C. \& Wielgolaski, F.E. 1975. Hardangervidda, Norway. Ecol. Bull. (Stockholm) 20: 225-264.

Ottoson, U., Ottvall, R., Elmberg, J., Green, M., Gustafsson, R., Haas, F., Holmqvist, N., Lindström, Å., Nilsson, L. Svensson, M., Svensson, S. \& Tjernberg, M. 2012. Fåglar i Sverige - antal och förekomst. Sveriges ornitologiska förening, Halmstad. (In Swedish, English species account summaries.)

Ottvall, R., Edenius, L., Elmberg, J., Engström, H. Green, M., Holmqvist, N., Lindström, Å., Tjernberg, M. \& Pärt, T. 2008. Populationstrender för fågelarter som häckar i Sverige. Naturvårdsverket. Electronic publication, ISBN 978 91-620-5813-5.pdf

Pan-European Common Bird Monitoring Scheme. 2011. Trends of common birds in Europe, 2011 update. European Bird Census Council, Prague. (www.ebcc.info/ index.php?ID=457)

Siegel, S. \& Castellan, N.J. Jr. 1988. Nonparametric statistics for the behavioral sciences. McGraw-Hill, New York.

Strand, O., Bevanger, K. \& Falldorf, T. 2005. Reinens bruk av Hardangervidda - sluttrapport fra Rv-7-ptosjektet. NINA Rapport 131.

Svensson S. 2006. Species composition and population fluctuations of alpine bird communities during 38 years in the Scandinavian mountain range. Ornis Svecica 16: 183-210.

Thompson, D.B.A., Kålås, J.A. \& Byrkjedal, I. 2012. Arcticalpine mountain birds in Northern Europe: contrasts between specialists and generalists. Pp. 237-252 in Fuller, R. (ed.). Birds and Habitat: Relationships in Changing Landscapes. Ecological Reviews Series, Cambridge University Press, Cambridge, UK.

Yablokov, A.V. 2009. Chernobyl's radioactive impact on fauna. Annals of the New York Academy of Sciences 1181: 255-280.

Yablokov, A.V., \& Nesterenko, V.B. 2009. Chernobyl contamination through time and space. Annals of the NewYork Academy of Sciences 1181: 5-30.

Received 19 April 2012. Accepted 25 September 2012 